\title{
The Comparison of the Imperial Palace of China and Buckingham Palace of the United Kingdom
}

\author{
Chuandai Qiao
}

School of foreign language, Hubei University of Automotive Technology, Shiyan442002, China

Keywords: Forbidden City, Buckingham Palace, cultural differences.

\begin{abstract}
Both the Imperial Palace in Beijing and Buckingham Palace in Britain are masterpieces of architecture and the typical representatives of Chinese and Western Royal architecture. By making a comparison between Chinese Imperial Palace and British Buckingham Palace, we can better explore the cultural differences between China and the west.
\end{abstract}

\section{Introduction}

The Imperial Palace in Beijing (the full name is the Imperial Palace Museum in Beijing) formerly known as the Forbidden City, is located in the center of the axle wire of Beijing. It used to serve as the Royal Palace for 24 kings in both Ming and Qing dynasties. The Imperial Palace is not only the essence of palace building of Han people in ancient China and the unparalleled masterpiece of architecture, but also one of the world's largest existing and best preserved ancient wooden structure buildings. It has more than 70 palaces, 9000 rooms, centering on three big halls, namely the Hall of Supreme Harmony, the Hall of Central Harmony and the Hall of Preserving Harmony. Buckingham Palace is mainly serving as the bedroom and office of the British monarch in London. Located in Westminster, it is one of the places where national celebration and royal welcome ceremony are held, and also an important tourist attraction. Besides, Buckingham Palace is also an important gathering place at the celebration moment or trying moment in the history of the United Kingdom.

\section{The Influence of the History and Culture of the Imperial Palace on Its Architecture}

The Imperial Palace, known as the Forbidden City, was the home to 24 Ming and Qing emperors, off-limits for 500 years. It stands in the center of Bejing, covering 720, 000square meters, owning 800 buildings and 9999 rooms, constituting a priceless testimony to Chinese civilization during the Ming and Qing dynasties. It is the largest and most magnificent group of palaces existing in China and a treasure house of various relics. It is also perfectly maintained. In Chinese, the Forbidden city is called Purple City, which was inaccessible to the common people during the reign of the emperors. Even the highest civil and military officers were not allowed to enter it without proper reason. The Imperial Palace is one of the architectural wonders of the world.

The Forbidden City was built in 1406, A.D. (the fourth year of Emperor Yongle's reign), and was finished in 1420, A.D. (the eithteenth year of Emperor Yonghe's reign), altogether taking 14 years. In 1406, on the basis of the palace in Dadu of Yuan Dynasty, Emperor Chengzu in Ming Dynasty began to sent about more than one million workers to build the palace for himself, taking the imperial palace of Nanjing as the model. The construction covers 720 thousand square meters (961 meters long from north to south and 754 meters wide from west to east), with a building area of 155 thousand square meters. Since it was completely finished, the Forbidden City had gone through the Ming and Qing dynasties, served as the home to 24 emperors for more than 500 years, which was the highest ruling core of both Ming and Qing dynasties. During the history of 500 years, all the royal events including the activities of emperors or empresses, power struggle, religious worship, etc. all happened in the palace.

From the perspective of Chinese traditional culture, the three great halls and their pedestals stand in the center of the Forbidden City, forming a shape of Chinese character "“"earth” in plane. This kind 
of layout is in accordance with the rule of ancient "heavenly Palace" or "Temple of Emperor" consisting of gold, wood, water, fire and soil chambers among which soil chamber was in the center in space. The centered-halls symbolize the "Imperial Ancestral Temple" of the "Heavenly palace". Between the five imperial gates offices were set for Nine Ministers and behind them there were where the five wives of emperor and their maids lived. Thus it can be seen that this kind of spatial arrangement is not made at random, but had its architectural culture and heritage. The building of ancient Chinese capital was mainly to highlight the majesty and dignity of emperor. The architectural space reflects the philosophy of harmony between the heaven and earth, yin and yang, and political stable and economic prosperous. The construction itself forms a shape of Chinese character "work" in space, and ends up with a form of quadrangle countyard covering a small patch of world, which is just in accord with Chinese traditional ideology of pursuing the harmony of the heaven and earth, yin and yang without focusing on individual independence of people as the subject. Chinese traditional Confucian etiquette thought had made people form distinct hierarchy deep in mind which became the basis of rank order in Chinese traditional architecture, appearing the implied meaning of "lofty and majesty" in palace construction. At the same time, the Confucian doctrine of the mean led to "the theory of moderation" running throughout Chinese ancient architecture, which insisted that buildings should be constructed in a moderate degree. The buildings of the Imperial Palace also echo this awareness. The buildings of the outer court of the Imperial Palace are in accord with the dominant ideology of "lofty and majesty"; while buildings of the inner court were constructed according to "the theory of moderation". Pass through the three halls of the outer court, and you will enter the Gate of Heavenly Purity with a sudden contraction in terms of building and special scale where the environment and atmosphere is suitable for private living. Comparing with back three palaces on the center axis---Palace of Heavenly Purity, Hall of Union and Palace of Earthly Tranquility, the east-west trend Palace of Gathering Excellence and Zhong Cui Palace, etc are much smaller in scale and very peaceful with pleasant indoor space, which almost are the same with quadrangle dwellings in Beijing. People who live here will not feel empty and depressed for the huge and towering buildings nor will they fell confused and boring because of the quietness and darkness indoor. The overall spatial layout is in good order, full of tension and relaxation, integrating people and architecture together in nature. The buildings of the outer court of the Imperial Palace were designed in accord with the dominant idea of "magnificence and beauty". In spite of the fact that they are huge in scale, but as far as the building itself is concerned, they are far more uncoordinated comparing with the human scale. The small scale steps and handrails outdoor, the pleasant space indoor, etc create the atmosphere of "the theory of moderation" under the grand and magnificent momentum. After an elaborate handling, grandness and moderation reached a state of unity and harmony.

\section{The Influence of the History and Culture of Buckingham Palace on Its Architecture}

Buckingham Palace is located in Westminster. It is both the Royal Palace and residence of the British royal family. It is bordered by Green Park in the north and by St. James's Park in the east. The statue in front of the Palace is the Queen Victoria Memorial. There are 775 rooms for ceremony hall, music hall, banquet hall, gallery, etc. in the palace and vast expanse of Imperial Garden outside. The Queen's important state activities are to be held in Buckingham Palace and leaders of others countries are also to stay here during their visit. The palace is defended by the royal guards clothed in formal dress who practice in the square every morning. The main building of Buckingham Palace is five layers and has ancillary buildings including the Royal Gallery, Royal Horse and Royal Garden. The Royal Gallery and Royal horse are both open to the public. Each summer, there is a grand royal reception in the Royal Garden held by British Royal family. In the center of the square stands the gold-plated Queen Victoria Memorial, on top of which stands a statue of a Goddess with frying wings. Below the Queen Victoria Memorial there are steps where it is the best place to enjoy Buckingham Palace. The golden angel of Queen Victoria's image symbolized that the royal hopes to see the brilliance of Victorian era again. If the emperor flag is flying right above the palace, it means that the queen is still in the palace. 
The original building was constructed as a country house in 1705 by the duke of Buckingham, John Sheffield. King George III bought the house in 1761 for his wife as a private living place and had it altered by the architect, William Chambers. In 1826, King George IV started to expand the house into a palace with the help of the architect John Nash. Due to a lack of sufficient funding, the architect incorporated the existing house in the new palace. On the basis of maintaining the main building, Nash doubled the palace in scale by adding a new suite of rooms facing west beside the garden. Later, the north and south wings of Buckingham Palace were removed and around the central courtyard the Arch of Triumph---the marble arch ---was built to commemorate the British victory at battle of Trafalgar and Waterloo. In 1830, King George IV was dead and his brother King William IV sent Edward Blore to finish the rest part of the huge project. But the king never moved in the palace. In 1837, after Queen Victoria ascended the throne, she moved in Buckingham Palace. From then on, Buckingham Palace became the official residence of the British royal family and served as an important place where the queen summoned the prime minister, and where national celebration, reception and entertaining foreign guests and other important activities are held.

In 1840, after Queen Victoria and Prince Albert got married, they found there were no nurseries and few guest bedrooms in Buckingham Palace. So the fourth side of the palace was built to connect the south and north, which together formed a quadrangle. The original marble arch was transferred to the northeast corner of Hyde Park. The architect who was in charge of the project built the East Front. There is a spacious balcony on the east side of its facade where the royal family members traditionally appear in public. In addition, in 1847, an attic floor was added on the main body of the palace, and a marble frieze was added to decorate the exterior of the Marble Arch. During the Second World War, the palace was bombed by the German air force, and the chapel was destroyed by a bomb attack. After the war a Queen Gallery was built on this site and was open to the public in 1962 to exhibit royal collection. There are more than 600 halls where many paintings and exquisite mahogany furniture are collected. In the hall of art gallery there are over 100 portraits and statues of emperors and queens in the history of UK, creating a strong atmosphere of England in the 18th and 19th century. In November, 1992, Windsor Castle was on fire. In order to raise money for the repair, the queen announced in the spring of 1993 that Buckingham Palace was to be formally open to the public from August 7 - September 30. And as a rule, Buckingham Palace is open to the public from October to September each year, but only three places can be visited by tourists.

\section{References}

[1]. Alzue A, O’Leary J and Morrison A M. Cultural and heritage tourism: identifying niches for international travelers .The Journal of Travel and Tourism Studies, 1998.

[2]. Anthony Giddcns, 1990, The Consequences of Modernity, Cambridge: Polity Press

[3]. Helga Haftendorn, The security puzzle: Theory-Building and Discipline-Building in International Studies Quarterly, 1991.

[4]. Herbert D.Literary places, tourism and the heritage experience [J].Annals of Tourism Research, 2001.

[5]. Hohn Tomlinson, Cultural Imperialism, London: Pinter Publishers.1996. 